\title{
Nutritional value of rapeseed expeller cake for broilers: effect of dry extrusion*
}

\section{S. Smulikowska1, J. Czerwiński and A. Mieczkowska}

\author{
The Kielanowski Institute of Animal Physiology and Nutrition, \\ Polish Academy of Sciences \\ 05-110 Jabłonna, Poland
}

(Received 21 December 2005; revised version 15 February 2006; accepted 5 July 2006)

\begin{abstract}
The effect of extrusion, applied in the production of cold-pressed rapeseed cake on its nutritional value for broilers was evaluated. Two experiments were performed on 55 female broiler chickens, kept individually and allocated to 2 groups of 14 birds (growth trial) or to 3 groups of 9 chickens (digestibility trial). Rapeseed cakes pressed once (RC) or extruded and pressed again (RCE) were mixed in a 6:4 proportion with a basal diet and used in a balance trial with 3-week-old chickens. Furthermore, they were included into wheat-soyabean meal diets at a level of 100 or $150 \mathrm{~g} / \mathrm{kg}$ and fed during 1-3 and 4-6 weeks of age, respectively, in a growth trial.

Due to extrusion and additional pressing, the amount of crude fat decreased from $17.4 \%$ in $\mathrm{RC}$ to $10 \%$ in REC, fat digestibility increased from 83 to $91 \%(\mathrm{P}<0.01)$, protein digestibility decreased from 79 to $76 \%(\mathrm{P}<0.01)$, and the metabolizable energy value decreased from 13.8 to $11.4 \mathrm{MJ} / \mathrm{kg}$ $\mathrm{DM}(\mathrm{P}<0.01)$. Broilers ate more of the REC diet compared with the RC diet and their final body weight gain was higher $(2.61 \mathrm{vs} 2.39 \mathrm{~kg} ; \mathrm{P}<0.05)$. This, as well as a lower relative mass of the liver $(\mathrm{P}<0.05)$ and kidneys $(\mathrm{P}<0.01)$ and a slightly lower mass of thyroids, indicates that extrusion resulted in partial inactivation of the antinutritional factors present in rape seeds.
\end{abstract}

KEY WORDS: rapeseed expeller cake, dry extrusion, metabolizable energy, broiler chickens, antinutritional factors

\section{INTRODUCTION}

The share of rapeseed expeller cake (RC) in Polish rapeseed products is growing because expelling technology is more cost-effective and more environmentally

\footnotetext{
* Preliminary results were presented at the 27th Scientific Conference on Oilseed Crops, Poznań (Poland), 2005

${ }^{1}$ Corresponding author: e-mail: s.smulikowska@ifzz.pan.pl
} 
friendly than the prepressing/solvent extraction method yielding rapeseed meal as the final product. Rapeseed cakes seem to be more suitable components of broiler diets than solvent-extracted rapeseed meal as their metabolizable energy value is higher than that of rapeseed meal due to a higher residual oil content (Smulikowska et al., 1997, 2006). Moreover, the residual oil has a lower n-6/n-3 PUFA ratio than most of the fats used in broiler diets. Nguyen et al. (2003) showed that broilers fed diets with rapeseed oil deposited fat with a low n-6/n-3 PUFA ratio in edible parts of the carcass, which can be considered beneficial for consumer health.

A number of technologies have been developed to improve oil yield by expelling, but so far their effect on the digestibility of fat and protein from $\mathrm{RC}$ is poorly understood. Rapeseed contains considerable proportions of non-protein components, primarily fibre. Fibre encapsulates fat and protein, hinders pressing out oil during expelling and impedes digestion of $\mathrm{RC}$ fat and protein in monogastric species. As a result, there is a potential for RC to derive additional value from partial disruption of fibre structures due to extrusion or the ammonia fibre explosion process (Newkirk and Classen, 2003). Apart from oil yield, additional treatments may affect myrosinase activity and glucosinolate toxicity, as well as protein digestibility and lysine availability in the final product (Smulikowska et al., 1997, 2006).

The aim of this study was to evaluate the effect of dry extrusion on the digestibility of RC nutrients, and on the performance and thyroid status in broiler chickens.

\section{MATERIAL AND METHODS}

\section{Materials}

Rapeseed press cakes were produced in a small rural mill (Kamex, Sulechów, Poland) from seeds harvested in the year 2003. Rape seeds were heated to $50^{\circ} \mathrm{C}$ and pressed on a screw press expeller (02PVO Bispomasz, Bydgoszcz, Poland), producing sample RC, or immediately extruded $\left(120-130^{\circ} \mathrm{C}\right.$ for $\left.20 \mathrm{sec}\right)$ on an FE 1000 dry extruder (Farmet, Czech Republic) and pressed again on the same press, producing sample RCE (Table 1). Finally both samples were formed into flakes and were ground prior to inclusion into the experimental diets.

\section{Diets and animals}

The composition of the basal diet (B) used in the digestibility trial is given in Table 2. Two test diets were composed of diet B mixed with RC or RCE in a 6:4 
Table 1. Chemical composition of rapeseed expeller cakes (g/kg DM), glucosinolate contents $(\mu \mathrm{mol} / \mathrm{g}$ air-dry matter) and protein solubility, \%

\begin{tabular}{|c|c|c|}
\hline Item & $\mathrm{RC}^{1}$ & $\mathrm{RCE}^{2}$ \\
\hline \multicolumn{3}{|l|}{ Component } \\
\hline $\mathrm{DM}, \mathrm{g} / \mathrm{kg}$ & 915 & 927 \\
\hline gross energy, $\mathrm{MJ} / \mathrm{kg} \mathrm{DM}$ & 25.2 & 23.2 \\
\hline crude protein & 311 & 358 \\
\hline crude fat ${ }^{3}$ & 174 & 101 \\
\hline crude ash & 55 & 63 \\
\hline crude fibre & 125 & 144 \\
\hline $\mathrm{N}$-free extractives & 335 & 334 \\
\hline NDF & 274 & 281 \\
\hline NDIN (NDF-bound protein), $\%$ total & 7.5 & 7.0 \\
\hline total P & 9.1 & 10.6 \\
\hline phytate P & 4.9 & 4.6 \\
\hline lysine available, $\mathrm{g} / 16 \mathrm{~g} \mathrm{~N}$ & 5.09 & 5.07 \\
\hline alkenyl-glucosinolates & 18.1 & 21.1 \\
\hline total glucosinolates & 23.3 & 26.8 \\
\hline \multicolumn{3}{|l|}{ Protein solubility, \% } \\
\hline in $0.5 \% \mathrm{KOH}(\mathrm{NSI})$ & $94.3^{\mathrm{A}}$ & $86.4^{\mathrm{B}}$ \\
\hline in borate & $91.9^{\mathrm{A}}$ & $53.9^{\mathrm{B}}$ \\
\hline Protein dispersibility index (PDI) & $40.1^{\mathrm{A}}$ & $25.3^{\mathrm{B}}$ \\
\hline
\end{tabular}

${ }^{1}$ rapeseed cake pressed once; ${ }^{2}$ rapeseed cake extended and pressed again; ${ }^{3}$ after acid hydrolysis

$\mathrm{A}, \mathrm{B}$ means in rows with different superscripts are significantly different at $\mathrm{P}<0.001$

proportion on DM basis. The composition of the diets used in the growth trial is also given in Table 2. The cakes were included at the level of 100 and 150 $\mathrm{g} / \mathrm{kg}$ diets fed during days 1-21 and 22-42 of age, respectively. Diet B used in the balance trial and the diets used in the growth trial were supplemented with $1 \mathrm{~g} / \mathrm{kg}$ of the enzyme preparation Avizyme 1300 (Finnfeeds, Danisco Cultor, containing $2500 \mathrm{U}$ endo-1,4-beta-xylanase and $800 \mathrm{U}$ subtilisin (protease) per gram, according to the producer's declaration). All diets were cold pelleted on a CL-2 CPM Laboratory Pellet Mill.

Two experiments were performed. The digestibility trial comprised 3 groups of three-week-old broilers, 9 birds per group. The birds were housed individually in balance cages. In the balance trial, they were given $90 \mathrm{~g} / \mathrm{bird} /$ day of the respective diets, in three meals. After two days of preliminary feeding the birds were fasted for $14 \mathrm{~h}$, then given the same diets for 3 days and again fasted for $14 \mathrm{~h}$. Feed intake was recorded daily, while during the last $86 \mathrm{~h}$ of the experiment excreta were quantitatively collected, frozen and kept at $-18^{\circ} \mathrm{C}$ for further analysis. The chickens were then offered the same diets ad libitum and on the next day they 
were sacrificed, the abdominal cavity was opened and the contents of the jejunum, ileum and caeca were collected. Digesta from 2 birds were pooled for $\mathrm{pH}$ and viscosity measurement.

In the growth trial, two groups of one-day-old broiler females, 14 birds per group, were used. For the first week the chickens were kept in pens, on day 8 they were weighed and placed in individual cages. From the first day of life the birds were given the experimental diets ad libitum (Table 2). Body weight and

Table 2. Ingredients and nutrient composition of diets, $\mathrm{g} / \mathrm{kg}$

\begin{tabular}{|c|c|c|c|c|c|c|c|}
\hline \multirow{3}{*}{ Item } & \multirow{3}{*}{$\begin{array}{c}\text { Basal diet } \\
\text { in balance } \\
\text { trial }\end{array}$} & \multicolumn{6}{|c|}{ Diets used in growth trial } \\
\hline & & \multicolumn{2}{|c|}{$1-21 \mathrm{~d}$ of age } & \multicolumn{2}{|c|}{$22-35 \mathrm{~d}$ of age } & \multicolumn{2}{|c|}{$36-42 \mathrm{~d}$ of age } \\
\hline & & $\mathrm{RC}^{3}$ & $\mathrm{RCE}^{4}$ & $\mathrm{RC}$ & RCE & $\mathrm{RC}$ & RCE \\
\hline \multicolumn{8}{|l|}{ Components } \\
\hline rapeseed cake & - & 100.0 & - & 150.0 & - & 150.0 & - \\
\hline rapeseed cake extruded & - & - & 100.0 & - & 150.0 & - & 150.0 \\
\hline wheat & 352.8 & 311.7 & 317.8 & 347.2 & 356.4 & 371.2 & 380.1 \\
\hline soyabean meal & 380.6 & 317.3 & 304.6 & 240.7 & 221.7 & 211.3 & 192.5 \\
\hline maize & 200.0 & 200.0 & 200.0 & 200.0 & 200.0 & 200.0 & 200.0 \\
\hline limestone & 3.4 & 3.6 & 3.6 & 4.5 & 4.5 & 2.3 & 2.2 \\
\hline dicalcium phosphate & 18.0 & 17.0 & 17.0 & 14.7 & 14.7 & 14.5 & 14.5 \\
\hline lard & 30.0 & 35.4 & 42.0 & 28.0 & 37.8 & 35.8 & 45.8 \\
\hline L-lysine $(78 \%)$ & 1.0 & 1.0 & 1.0 & 0.9 & 0.9 & 0.9 & 0.9 \\
\hline DL-methionine (98\%) & 0.2 & - & - & - & - & - & - \\
\hline $\mathrm{NaCl}$ & 3.0 & 3.0 & 3.0 & 3.0 & 3.0 & 3.0 & 3.0 \\
\hline Avizyme 1300 & 1.0 & 1.0 & 1.0 & 1.0 & 1.0 & 1.0 & 1.0 \\
\hline Premix $^{1,2}$ & $10.0^{1}$ & $10.0^{1}$ & $10.0^{1}$ & $10.0^{1}$ & $10.0^{1}$ & $10.0^{2}$ & $10.0^{2}$ \\
\hline \multicolumn{8}{|l|}{ Calculated } \\
\hline crude protein & 222.7 & 220.0 & 220.0 & 205.0 & 205.0 & 195.0 & 195.0 \\
\hline crude fat & 50.0 & 70.0 & 70.0 & 70.2 & 70.3 & 78.0 & 78.0 \\
\hline \multicolumn{8}{|c|}{ 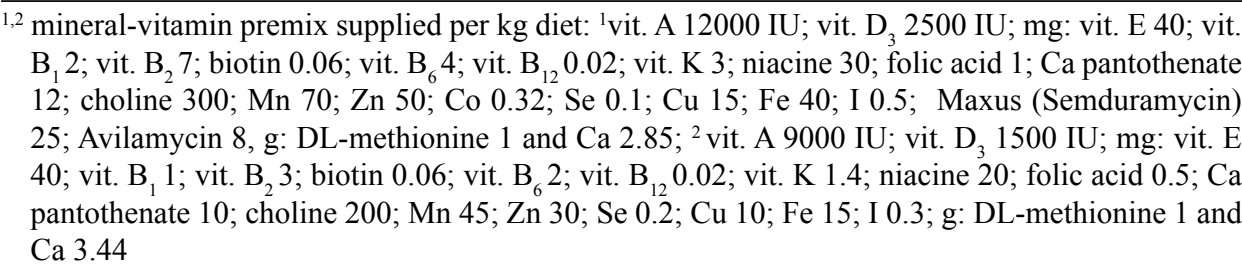 } \\
\hline
\end{tabular}

feed intake were measured in weekly intervals after $4 \mathrm{~h}$ food deprivation. At the end of experiment the birds were killed by cervical dislocation, the abdominal cavity was opened and the liver, thyroid glands, kidneys and abdominal fat were excised and weighed. 
Both experiments were conducted in compliance with the European Union regulations concerning the protection of experimental animals. The Local Ethics Committee approved the study protocol.

\section{Analysis and calculations}

The glucosinolate content in press cakes was measured according to ISO 9167-1 (1992). Protein solubility was determined in $0.5 \% \mathrm{KOH}$ (NSI) and in borate. Protein dispersibility in water (PDI) and the available lysine content in cakes were measured, and the contents of crude fat, $\mathrm{N}$ total, $\mathrm{N}$ faecal and gross energy in cakes, diets and excreta were determined as described by Smulikowska et al. (2006). Caecal contents were mixed with deionised water $(1: 1 \mathrm{w} / \mathrm{w})$ and their $\mathrm{pH}$ was immediately measured using a digital $\mathrm{pH}$-meter (WTW $\mathrm{pH} / 340$, Germany) against a pH standard WTW D-82362 Weilheim (model STP4) at room temperature. Jejunal and ileal digesta and diluted caecal contents were centrifuged at $10.000 \times \mathrm{g}$ for $10 \mathrm{~min}$ using a Beckman centrifuge (model J2-21 with $\mathrm{J}-20$ rotor) at $4{ }^{\circ} \mathrm{C}$ and the viscosity of the supernatant $(0.5 \mathrm{~mL}$ aliquot $)$ was immediately measured with the use of a Brookfield Digital cone/plate viscometer (model LVDV II+, Brookfield Engineering Laboratories, Stoughton, MA, USA). Readings were expressed in centipoise $(1 \mathrm{cP}=1 \mathrm{MPa} \cdot \mathrm{s})$.

The apparent protein and fat digestibility and metabolizable energy value of press cakes were calculated by the difference method as described by Smulikowska et al. (2006). The results were subjected to one-way analysis of variance (ANOVA) generated by Statgraphics ${ }^{\circledR}$ ver. 5.1 (1994-2001).

\section{RESULTS}

Due to extrusion and additional pressing, the crude fat content decreased, while the concentration of the remaining components in RCE increased in comparison with RC (Table 1). The glucosinolate content in RCE was also higher than in RC, so the respective diets used in the growth trial contained 1.8 or $2.1 \mu \mathrm{mol} / \mathrm{g}$ of aliphatic glucosinolates during the first 3 weeks and 2.7 or $3.2 \mu \mathrm{mol} / \mathrm{g}$ in the later period (Table 2). The protein solubility indexes were significantly lower in RCE than in $\mathrm{RC}(\mathrm{P}<0.001)$, whereas the NDF-bound protein content in RCE, slightly decreased (Table 1).

The apparent protein digestibility, $\mathrm{N}$ retention, organic matter retention, apparent metabolizable energy value and energy metabolizability were lower $(\mathrm{P}<0.01)$, while fat digestibility was higher $(\mathrm{P}<0.01)$ in RCE than in RC (Table 3 ). In the balance trial, the viscosity of digesta in group RC did not differ from 
Table 3. Effect of extrusion on apparent protein and fat digestibility, $\mathrm{N}$ and organic matter retention and metabolizable energy value of non-extruded (RC) and extruded (RCE) rapeseed cakes (balance trial)

\begin{tabular}{lcccccc}
\hline Treatment & $\begin{array}{c}\text { Apparent } \\
\text { protein } \\
\text { digestibility } \\
\%\end{array}$ & $\begin{array}{c}\text { Apparent fat } \\
\text { digestibility } \\
\%\end{array}$ & $\begin{array}{c}\mathrm{N} \\
\text { retention } \\
\%\end{array}$ & $\begin{array}{c}\text { Organic matter } \\
\text { retention } \\
\%\end{array}$ & $\begin{array}{c}\mathrm{AME}_{\mathrm{N},} \\
\mathrm{MJ} / \mathrm{kg} \mathrm{DM}\end{array}$ & $\begin{array}{c}\mathrm{AME}_{\mathrm{N}} / \mathrm{GE} \\
\%\end{array}$ \\
\hline $\mathrm{RC}$ & $78.7^{\mathrm{A}}$ & $82.9^{\mathrm{A}}$ & $44.7^{\mathrm{A}}$ & $53.0^{\mathrm{A}}$ & $13.86^{\mathrm{A}}$ & $55.1^{\mathrm{A}}$ \\
$\mathrm{RCE}$ & $75.9^{\mathrm{B}}$ & $90.9^{\mathrm{B}}$ & $36.6^{\mathrm{B}}$ & $45.1^{\mathrm{B}}$ & $11.39^{\mathrm{B}}$ & $48.7^{\mathrm{B}}$ \\
SEM & 0.35 & 0.90 & 1.21 & 0.83 & 0.15 & 0.6 \\
\hline
\end{tabular}

$\mathrm{A}, \mathrm{B}$ means in columns with different superscripts were significantly different at $\mathrm{P}<0.01$

the group fed the basal diet, but in the RCE group the viscosity of jejunal digesta was significantly lower $(\mathrm{P}<0.01)$, while the ileal digesta viscosity was numerically lower than in the other groups. Viscosity of the caecal digesta was most variable and was numerically higher in the RCE group (Table 4). In both groups fed diets with rapeseed cakes, the $\mathrm{pH}$ of the caecal digesta was lower $(\mathrm{P}<0.01)$ than in the group fed the basal diet (Table 4).

Table 4. Viscosity of digesta and $\mathrm{pH}$ in caecal contents in chickens fed diets used in the balance trial

\begin{tabular}{lcccc}
\hline \multirow{2}{*}{ Dietary treatment } & \multicolumn{3}{c}{ Viscosity of digesta, mPas s } & \multirow{2}{*}{$\begin{array}{c}\mathrm{pH} \text { of caecal } \\
\text { contents }^{1}\end{array}$} \\
\cline { 2 - 4 } & jejunum & ileum & caeca $^{1}$ & \\
\hline Basal & $1.27^{\mathrm{A}}$ & 1.76 & 1.47 & $6.81^{\mathrm{A}}$ \\
RC & $1.29^{\mathrm{A}}$ & 1.95 & 1.56 & $5.95^{\mathrm{B}}$ \\
RCE & $1.09^{\mathrm{B}}$ & 1.62 & 2.61 & $5.82^{\mathrm{B}}$ \\
SEM & 0.03 & 0.12 & 0.47 & 0.16 \\
\hline
\end{tabular}

${ }^{1}$ caecal contents were diluted with deionised water 1:1 (w/w)

${ }_{A, B}$ means in the same column with different superscripts are significantly different at $\mathrm{P}<0.01$

In the growth trial, broilers fed the RCE diet ate more than broilers fed the RC diet $(\mathrm{P}<0.01)$ and the body weight gain was significantly $(\mathrm{P}<0.05)$ higher in the RCE group during the first 3 weeks of life and during the whole period (Table 5). In RCE birds there was tendency towards the weight of the thyroid to decrease, whereas the liver weight was significantly $(\mathrm{P}<0.05)$ lower and the kidney weight, highly significantly $(\mathrm{P}<0.01)$ lower than in $\mathrm{RC}$ birds (Table 6). The abdominal fat weight was higher $(\mathrm{P}<0.01)$ in group RCE than in RC.

Table 5. Effect of extrusion on performance of chickens (growth trial)

\begin{tabular}{lccccccccc}
\hline \multirow{2}{*}{ Treatment } & \multicolumn{3}{c}{ Feed intake, g } & \multicolumn{3}{c}{ Body weight gain, g } & \multicolumn{3}{c}{ FCR, g feed/g BWG } \\
\cline { 2 - 9 } & $1-21 \mathrm{~d}$ & $22-42 \mathrm{~d}$ & $1-42 \mathrm{~d}$ & $1-21 \mathrm{~d}$ & $22-42 \mathrm{~d}$ & $1-42 \mathrm{~d}$ & $1-21 \mathrm{~d}$ & $22-42 \mathrm{~d}$ & $1-42 \mathrm{~d}$ \\
\hline RC & $1011^{\mathrm{A}}$ & $1802^{\mathrm{A}}$ & $3951^{\mathrm{A}}$ & $765^{\mathrm{a}}$ & 1083 & $2386^{\mathrm{a}}$ & $1.32^{\mathrm{a}}$ & 1.67 & 1.66 \\
RCE & $1130^{\mathrm{B}}$ & $1991^{\mathrm{B}}$ & $4399^{\mathrm{B}}$ & $833^{\mathrm{b}}$ & 1163 & $2612^{\mathrm{b}}$ & $1.36^{\mathrm{b}}$ & 1.72 & 1.68 \\
SEM & 21 & 44 & 90 & 18 & 31 & 59 & 0.01 & 0.02 & 0.02 \\
\hline
\end{tabular}

a,b,A,B means in the same column with different superscripts are significantly different at:

${ }^{a, b} \mathrm{P}<0.05$; ${ }^{\mathrm{A}, \mathrm{B}} \mathrm{P}<0.01$ 
Table 6. Effect of extrusion on the weight of organs and abdominal fat in 42-day-old chickens (growth trial)

\begin{tabular}{lcccc}
\hline \multirow{2}{*}{ Treatment } & \multicolumn{4}{c}{ Weight of organs per $100 \mathrm{~g}$ live body weight } \\
\cline { 2 - 5 } & thyroids, mg & liver, g & kidneys, mg & abdominal fat, g \\
\hline RC & 17.9 & $2.41^{\mathrm{a}}$ & $886^{\mathrm{A}}$ & $1.14^{\mathrm{A}}$ \\
RCE & 16.8 & $2.18^{\mathrm{b}}$ & $690^{\mathrm{B}}$ & $1.44^{\mathrm{B}}$ \\
SEM & 1.22 & 0.07 & 16 & 0.07 \\
\hline
\end{tabular}

$\mathrm{a}, \mathrm{b}, \mathrm{A}, \mathrm{B}$ means in the same column with different superscripts are significantly different at:

${ }^{\mathrm{a}, \mathrm{b}} \mathrm{P}<0.05 ;{ }^{\mathrm{A}, \mathrm{B}} \mathrm{P}<0.01$

\section{DISCUSSION}

Due to extrusion and additional pressing, more oil was removed from rapeseed and therefore the RCE contained more protein and less GE than RC.

The protein solubility indexes used in the study have been shown to be a good indicator of protein quality in soyabean meals (Batal et al., 2000) as well as in rapeseed meals that were overprocessed during toasting (Pastuszewska et al., 1998). In the present study, dry heat applied for a short time during extrusion substantially lowered the protein solubility indexes determined in vitro (by 8, 37 and $41 \%$ ). This was not connected, however, with protein damage as the available lysine content was on the same level before and after extrusion. Most probably, extrusion promoted creation of insoluble complexes from protein and dietary fibre components. Nguyen et al. (2003) reported that the jejunal digesta from chickens fed rapeseed or soyabean-based diets were of similar viscosity, which was confirmed in this study. The viscosity of jejunal digesta was significantly lower, however, in the RCE group in comparison with the RC group. This supports the hypothesis on insolubilization of part of the soluble dietary fibre components due to extrusion.

The difference between the effect of extrusion on apparent total tract protein digestibility (3.6\% lower in RCE) and on N retention (18\% lower in the RCE group in comparison with the $\mathrm{RC}$ group) indicated that protein associated with dietary fibre was hydrolysed more distally by the microflora, whereby the degradation products were not utilized by the birds.

The lower protein digestibility and lower nitrogen retention from RCE resulted in a worse feed conversion ratio, especially during the first 3 weeks. Finally, the RCE chickens deposited more adipose tissue in the body in comparison with the $\mathrm{RC}$ group.

Similarly as in our previous study with broilers (Smulikowska et al., 2006) and in the study by Keith and Bell (1991) on pigs, there were no apparent palatability problems associated with the feeding of both types of rapeseed cake. Broilers fed the RCE diet consumed more feed than those fed the RC diet, which resulted in 
a higher final body weight. Part of the improvement may probably be related to the deactivation of myrosinase in the cake. In intact rape seeds myrosinase and glucosinolates are located in separate cellular compartments (Maheshwari et al., 1981) and crushing the seeds brings them into contact. Myrosinase hydrolyses glucosinolates, and the generated degradation products such as thiocyanates, 5-vinyl-oxazolidine-2-thione, 1-cyano-2-hydroxy-3-butene, isothiocyanates or nitriles have adverse effects on the physiological status of the thyroid, liver and kidneys and on growth performance. Inactivation of myrosinase by heat treatment prior to processing is advised (Bell, 1993). Shires et al. (1983) cited by Newkirk and Classen (2002) reported that heating canola meal to $100^{\circ} \mathrm{C}$ improved feed intake and growth rate in broilers. The smaller thyroids as well as the significantly lower weight of the liver and kidneys in the RCE group in comparison with the $\mathrm{RC}$ group indicated that extrusion inactivated the myrosinase in the cake.

Newkirk and Classen (2003) reported that the ammonia fibre explosion technology (extrusion connected with injecting ammonia) has a great potential for improving the utilization of rapeseed by poultry. From a practical point of view, it is important to know if extrusion improves the digestibility of nutrients in RC. The fat digestibility in RCE was 8 percentage points higher than in RC, which indicates that part of the oil in RC was encapsulated by fibre and therefore indigestible. Partial disruption of fibre structures due to extrusion increased residual fat utilization, however, it was accompanied by a 2.8 percentage point reduction in protein digestibility. As a result, the metabolizable energy value of RCE as well as energy metabolizability were lower than in RC, mainly due to less oil remaining in the cake. The $\mathrm{AME}_{\mathrm{N}}$ values of RC and RCE were much higher than in solvent-extracted rapeseed meal $(8.25 \mathrm{MJ} / \mathrm{kg} \mathrm{DM})$ and higher than in rapeseed meal expeller double zero $(10.25 \mathrm{MJ} / \mathrm{kg} \mathrm{DM})$ given in European Tables (1989). In practice, both types of cakes may be used to replace part of the soyabean meal in broiler diets, reducing the need for supplemental fat. Complete replacement of soyabean meal by rapeseed cake is not advised, as it may impair performance.

\section{CONCLUSIONS}

It may be concluded that pressing and extrusion of rapeseed reduced the antinutritional effect of glucosinolates. This resulted in an improved feed intake and body weight gain, however, the metabolizable energy of extruded cakes decreased in comparison with pressed cake. 


\section{REFERENCES}

Batal A.B., Douglas M.W., Engram A.E., Parsons C.M., 2000. Protein dispersibility index as an indicator of adequately processed soybean meal. Poultry Sci. 79, 1592-1596

Bell J.M., 1993. Factors affecting the nutritional value of canola meal: a review. Can J. Anim. Sci. 73, 679-697

European Tables of Energy Values for Poultry Feedstuffs, 1989. Working Group No. 2, Nutrition, European Federation of Branches of the WPSA, Beekbergen (The Netherlands)

ISO 9167-1, 1992. Rapeseed - Determination of glucosinolate content. Part 1. Method using gradient elution high performance liquid chromatography

Keith M.O., Bell J.M., 1991. Composition and digestibility of canola press cake as a feedstuff for use in swine diets. Can. J. Anim. Sci. 71, 879-885

Maheshwari P.N., Stanley D.W., Beveridge T.J., Van de Voort F.R., 1981. Localization of myrosinase (thioglucoside glucohydrolase, EC. 3.2.3.1) in cotyledon cells of rapeseed. J. Food Biochem. 5, 39-61

Newkirk R.W., Classen H.L., 2002. The effects of toasting canola meal on body weight, feed conversion efficiency, and mortality in broiler chickens. Poultry Sci. 81, 815-825

Newkirk R.W., Classen H.L., 2003. Technological treatments to improve quality of protein sources. Proceedings of 14th European Symposium on Poultry Nutrition, Lillehammer (Norway), pp. $8-13$

Nguyen C.V., Smulikowska S., Mieczkowska A., 2003. Effect of linseed and rapeseed or linseed and rapeseed oil on performance, slaughter yield and fatty acid deposition in edible parts of the carcass in broiler chickens. J. Anim. Feed Sci. 12, 271-288

Pastuszewska, B., Buraczewska L., Ochtabińska A., Buraczewski S., 1998. Protein solubility as an indicator of overheating rapeseed oilmeal and cake. J. Anim. Feed Sci. 7, 73-82

Smulikowska S., Pastuszewska B., Mieczkowska A., Ochtabińska A., 1997. Chemical composition, energy value for chickens, and protein utilization in rats of rapeseed expeller cakes produced by different pressing technologies. J. Anim. Feed Sci. 6, 109-121

Smulikowska S., Mieczkowska A., Czerwiński J., Weremko D., Nguyen C.V., 2006. Effects of exogenous phytase in chickens fed diets with differently processed rapeseed expeller cakes. J. Anim. Feed Sci. 15, 237-252

Statgraphics ${ }^{\circledR}$ ver. 5.1., 1994-2001. Statistical Graphic System by Statistical Graphic Corporation (USA) 